\title{
Local Government and Women
}

\section{OPEN ACCESS}

Volume: 6

Issue: 4

Month: April

Year: 2019

ISSN: 2321-788X

Received: 15.03.2019

Accepted: 30.03.2019

Published: 02.04.2019

Citation:

Rajiakodi, M., and

Dushyantraj Sahibram

Mallick. "Local

Government and

Women." Shanlax

International Journal

of Arts, Science and

Humainties, vol. 6, no. 4, 2019, pp. 1-4.

DOI:

https://doi.org/10.34293/

sijash.v6i4.366

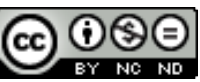

This work is licensed under a Creative Commons AttributionNonCommercial-

NoDerivatives 4.0 International License

\author{
M.Rajiakodi \\ Former Dean, Madurai Kamaraj University \\ Madurai, Tamil Nadu, India
}

\section{Dushyantraj Sahibram Mallick}

Research Scholar, Department of Rural Development Economics

School of Economics, Madurai Kamaraj University

Madurai, Tamil Nadu, India

\section{Abstract}

The 73rd Constitutional Amendment Act 1992 has made two important provisions for the involvement of women in decision making and preparation of plan for development. Let us elaborate it. This amendment has made a provision that at least one -third of women would be members and chairpersons of the Panchyats at three levels means at Gram Panchayat level, Panchayat Samiti level and Zilla Panchayat level. These women also include from scheduled caste and scheduled tribe communities. Secondly, Panchayats are also expected to prepare plans for economic development including the 29 subjects listed in the Eleventh Scheduled of the constitution. The rural plan prepared by Zilla Parishads would be forwarded to District Planning Committee for preparing a consolidated plan for the rural and urban areas of the district. Now, this was the mandate given by the constitution for development of entire rural areas including women. Women would only be empowered if various developmental works which are undertaken are benefiting women.

Keywords: Gram Panchayat, Panchayat Samiti and Zilla Panchayat, Local Self Government, Kuda volai, 73rd Constitutional Amendment, NGO. WSHG, Women Political Empowerment

\section{Introduction}

The role of women in any activity - social, political, economic and cultural cannot be overemphasized. The importance of Panchayati-raj system has been in existence for a long time in India in some form or other. The culverts in Uthramerur in Chengai district amply show that village administration was conducted by holding elections through 'Kuda volai" system. This explains the advanced nature of people's culture and their love for democracy during the Chola period in Tamil Nadu

Even before independence, Mahatma Gandhi and other leaders stressed the need for "Village Swaraj" as the universal remedy for village administration and rural development.

\section{Women and Panchayati Raj}

Mahatma Gandhiji would have insisted upon women's equal participation and devotion of power to the institutions of local Self-Governance and the Village Panchayat. The Panchayat Raj Act provides for people's active participation in the local administration by granting them power to question and by requesting their participation in planning for development of their villages. The Self-Help Group women are mentally ready now and have moral courage to contest the local and Legislative election. There is every possibility that the growth of Self-Help Group in the future will provide large number of women leaders in India. 
The 73rd and 74th Amendments (1993) to the Indian Constitution is considered as a breakthrough towards ensuring equal access and increased participation in political power structure for women. At least at local level, the 73rd Constitutional Amendment Act 1992 has made two important provisions for the involvement of women in decision making and preparation of plan for development. Let us elaborate it. This amendment has made a provision that at least one -third of women would be members and chairpersons of the Panchyats at three levels means at Gram Panchayat level, Panchayat Samiti level and Zila Panchayat level. These women also include from scheduled caste and scheduled tribe communities. Secondly, Panchayats are also expected to prepare plans for economic development including the 29 subjects listed in the Eleventh Scheduled of the constitution. The rural plan prepared by Zilla Parishads would be forwarded to District Planning Committee for preparing a consolidated plan for the rural and urban areas of the district. Now, this was the mandate given by the constitution for development of entire rural areas including women. Women would only be empowered if various developmental works which are undertaken are benefiting women.

Great thinkers predict that in the new century, great importance will be given to women and spiritualism. Though women from historical days had played a dominant role in every aspect of human life in India, not much has been highlighted and stressed. They still remain a neglected segment of the society in India. The reservation of $33 \%$ under the Panchayati-raj Administration is a great milestone in the women's movement in India. There is also a lot of talk and propaganda on women empowerment. All these programmes are sweet to listen. But the crucial questions are

- Is the male dominated Indian society wholeheartedly supporting these movements and legislative measures?

- Have the women equipped themselves with the requisite knowledge, Skill, Energy, Outlook and forward looking character to assume the responsibilities assigned to them by various civic administration?
Even today there are people who critics that the new measures cannot empower women. They also say that women are deeply rooted in tradition and old beliefs and will not come up to the expectations.

Any impartial observer will have to admit that the women of India have crossed thousands of hurdles and prepared themselves to face any challenge in the developing nations like India. Leaving aside the urban women who have demonstrated their abilities in different walks of life, the rural women also are emerging as a powerful force through mass literacy, NGOs awareness programmes, participation of women in the different phases of Panchayati-raj administration and Women Self Help Groups.

We are witnessing a renaissance in the women's development at the grass root level. Gone are the days when women were asked to be mere listeners, marry good man and carry good children and take care of the kitchen. Now we have a new brand of womanhood rising at the village level with optimism and hard work. It is also relevant to mention that women groups have also become small scale entrepreneurs in the production of goods using agro based raw materials.

\section{Research Study on Women Panchayat Elected Representatives}

The purpose of this research is to describe the individuals, community, society and any other units under investigation. The basic thrust of this study is to gain familiarity and the insight to the role of women representatives in the Local Self Government (Panchayat Raj) in Thane district, Maharashtra .

Local Bodies in the Thane district includes, Zilla parishad, 7 Municipal Corporations, 5 Municipal Councils 13 Panchayat Samities

From these thirteen Panchayat Samities the researcher made a story among the female panchayat presidents at village level in Thane district.

We are happy to mention the findings of a research study conducted in the Thane district. The findings show that all elected women representatives are doing good work and involving themselves in the development activities in the villages. However, there are a few bottlenecks. In general a woman presiding over the Village Panchayat or a Union or a District Panchayat has to meet a number of difficulties. 
- She has to have the full support of her husband

- She has to have the full support of her family members

- She has to have the support and rapport of the officials.

- Lastly she has to have the support of the society in which she lives.

In many cases all the above mentioned support can not be expected. A study of Prof. Abdul Aziz on "Nagar Bala and Women participation in Karnataka State" founded by the World Bank has found that all is not well in the system. The women involved in Panchayati-raj System have to cross many hurdles.

These are all passing events and have to be tackled by means of number of measures like literacy for women, periodical in-service training in Panchayat administration to women elected representatives, providing awareness programmes etc. Literacy for rural women is an essential component of any rural development strategy. They have been carrying the burden of household activities, partnering their husbands in the times of Weal or Woe and taking care of the children. They have undergone countless sufferings. It is time that they are given their rightful due in the process of Rural Development and Nation building.

\section{Conclusion}

On the basis of the data collected and the conclusions reached in this study, it is observed that the women representatives need to be politically socialized by way of making them participate in an exclusive political oriented occasions. This would certainly pave the way for building up of their own self-confidence and thereby the overall control over the subordinates shall be maintained. This will be of great moral boost for the women representatives in order to fulfill their commitments in tune with expectations of rural masses in the respective pockets

It is worth quoting the words of wisdom of Gilbert Etienne, who spent nearly 30 years in traveling around rural India while undertaking social research (India's Changing Rural Scene, 19631979). "What a sight, in November or December, when the hard work on the soil is temporarily put aside, to see long processions of bullock carts going to the Ganges for the sacred bath. The men lead the bullocks, the women, wearing bright saris, sing to Gangaji, symbol of fertility and purification

\section{References}

Mullick, Rohit \& Raaj, Neelam. 9 September 2007. "Panchayats turn into kangaroo courts". The Times of India. Retrieved 7 June 2015.

Nath, Akshaya. "National Panchayat Raj Day: Here are few things that you need to know about Panchayat Raj" 24 April 2015.

SaddaHaq "The Constitution (Seventy-third Amendment) Act, 1992". Government of India. Archived from the original on 5 May 2003. Retrieved 4 June 2015.

Jump up to: India, Publications Division, "Ministry of Information and Broadcasting", Government of India, 2007 pp. 696

Sisodia, R. S. "Gandhiji's Vision of Panchayati Raj". Panchayat Aur Insan. 1971, vol.3 no. 2 pp.9-10. Hardgrave, Robert, L, Kochanek \& Stanley A. "India: Government and Politics in a Developing Nation (seventh ed.)". Boston, Massachusetts: Thomson/Wadsworth. 2008, p. 157. ISBN 9780-495-00749-4.

Singh \& Vijandra. "Chapter 5: Panchayate Raj and Gandhi, Panchayati Raj and Village Development: Vol. 3, Perspectives on Panchayati Raj Administration". StudiesinPublic Administration. New Delhi: Sarup \& Sons. 2003, pp. 84-90, ISBN 978-81-7625-392-5.

Sanchita Tripathi, "Women Leadership and PRIs", Kurukshetra, 2005.

Mahipal, "Panchayatiraj and Women", Kurukshetra 2015.

Lakhimi Dutta. "Panchayatiraj-Three tier system in India ", Kurukshetra, 2014.

Sapra \& Ipsita February 2013. "Living in the villages". Rural Democracy. D+C Development and Cooperation. Retrieved. 24 April 2015.

$50 \%$ reservation for women in panchayats - Oneindia News. News.oneindia.in (2009-08-27). Retrieved on 2013-07-28. 
International Journal of Arts, Science and Humanities

\section{Web Sources}

http://www.mathrubhumi.com/women/features/ mayor-malayalam-news-1.696624 http://www.mathrubhumi.com/women/news/lsgdwomans-malayalam-news- 1.694513

Website: publicationdivision .nic.in www.panchayat.nic.in

\section{Author Details}

Dr.M.Rajiakodi, Former Dean, Madurai Kamaraj University, Madurai, Tamil Nadu, India.

Email ID: rajiakodim@gmail.com

Dushyantraj Sahibram Mallick, Research Scholar, Department of Rural Development Economics, School of Economics, Madurai Kamaraj University, Madurai, Tamil Nadu, India. 